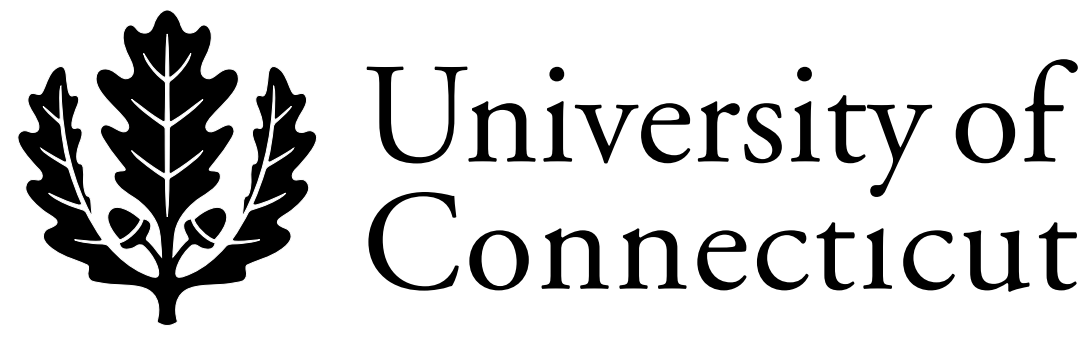

Department of Economics Working Paper Series

\title{
An Economic Theory of Mortgage Redemption Laws
}

Matthew J. Baker

U.S. Naval Academy

Thomas Miceli

University of Connecticut

C. F. Sirmans

University of Connecticut

Working Paper 2004-26

May 2004

341 Mansfield Road, Unit 1063

Storrs, CT 06269-1063

Phone: (860) 486-3022

Fax: (860) 486-4463

http://www.econ.uconn.edu/ 


\begin{abstract}
Redemption laws give mortgagors the right to redeem their property following default for a statutorily set period of time. This paper develops a theory that explains these laws as a means of protecting landowners against the loss of nontransferable values associated with their land. A longer redemption period reduces the risk that this value will be lost but also increases the likelihood of default. The optimal redemption period balances these effects. Empirical analysis of crossstate data from the early twentieth century suggests that these factors, in combination with political considerations, explain the existence and length of redemption laws.
\end{abstract}

Journal of Economic Literature Classification: K11 


\section{An Economic Theory of Mortgage Redemption Laws}

\section{Introduction}

Mortgage redemption laws, which grant a defaulting mortgagor a grace period to redeem the mortgaged property, are as ancient as the mortgage itself. For example, it is decreed in Leviticus 25:29-30 that:

If a man sells a house in a walled city, he retains the right of redemption a full year after its sale. During that time he may redeem it. If it is not redeemed before a full year has passed, the house in the walled city shall belong permanently to the buyer and his descendants. It is not to be returned in the Jubilee. But houses in villages without walls around them are to be considered as open country. They can be redeemed, and they are to be returned in the Jubilee. $^{1}$

Mortgage laws in the United States also have a long history that "bears the scars of the never-ending struggle between debtor and creditor" (Friedman, 1985: 246). While strong laws protecting creditors help both creditors and debtors by ensuring the flow of credit and promoting development, debtors invariably look to courts and legislatures for relief during economic downturns. Thus, the common law concept of "equity of redemption" emerged early on in English law to allow mortgagors to redeem their property following default up to a foreclosure date set by the court. And, beginning in

\footnotetext{
${ }^{1}$ This citation is due to Capone (1996). In fact, the whole chapter 25 of Leviticus concerns redemption.
} 
1820 , state legislatures in the U.S. began to pass laws that extended the redemption period beyond foreclosure (Skilton, 1943; Friedman, 1985: 247).

In spite of the enduring presence of mortgage redemption laws, economists have devoted relatively little attention to explaining their function. Exceptions include Alston (1984), who studied the causes and effects of mortgage foreclosure moratoria (temporary relief from foreclosure) enacted during the Great Depression; Jaffe and Sharp (1996), who discussed foreclosure moratoria as an efficient legislative response to unforeseen economic downturns, given the incompleteness of mortgage contracts; and Hynes, Malani, and Posner (2003), who examined the related issue of laws exempting property from bankruptcy proceedings. In this paper, we extend this literature by developing a theoretical model of mortgage redemption that is based on the divergence between the market valuation of land and the value placed on it by the mortgagor. Specifically, the theory hypothesizes the existence of a non-transferable component of mortgaged land that may arise when a mortgagor invests time and effort in learning how to best use his land. In the event that the mortgagor defaults on his mortgage, this value is lost because it is not capitalized by the market. A right of redemption reduces the risk of this loss by effectively extending the term of the mortgage. While such an extension strengthens the mortgagor's incentive to make investments in non-transferable capital, it also has the effect of lessening his incentive to avoid default in the first place. The desirability and optimal length of a redemption period turns on this trade-off.

To provide a context for the theory, Section II briefly examines the history of redemption laws in the United States. Following the theoretical analysis in Section III, Section IV offers some empirical evidence in support of the theory using cross-state data 
from the early twentieth century. Our empirical work contributes to the growing body of literature that seeks to understand the economic forces driving variations in state laws. ${ }^{2}$

\section{The Origins and History of State Mortgage Redemption Laws}

To provide some background for our analysis, we begin with a brief history of mortgage redemption laws in the United States. ${ }^{3}$ In its modern form, equity of redemption first appeared in $16^{\text {th }}$ Century English Law, when courts began to allow mortgagors to repay lenders after passage of the maturity date and thus reclaim possession of land. Gradually, the law developed into a system of equitable redemption coupled with strict foreclosure, under which foreclosure was initiated by petition from the mortgagee to extinguish the mortgagor's redemption rights. Upon petitioning, the court would fix a time period during which the mortgagor could redeem the land. After this time period had elapsed, the mortgagor's interest was terminated and the mortgagee would assume full possession of the land.

The chief drawback of the system was the substantial foreclosure costs inflicted on mortgagees due to the costliness of petitioning the court for a decree of foreclosure. The only way to extinguish the mortgagor's redemption right other than by petition was for the mortgagee to wait 20 years, at which point the mortgagor's interest was ended by prescription. Skilton (1943) conjectures that these shortcomings in the English foreclosure system may have contributed to the apparent diversity in American foreclosure and redemption laws by encouraging experimentation with other systems.

\footnotetext{
${ }^{2}$ See, for example, Baker and Miceli (2000), Baker, Miceli, Sirmans, and Turnbull (2001, 2002), and Glaeser and Scheinkman (2002).

${ }^{3}$ Much of this review of the early history of mortgage redemption relies on Skilton (1943).
} 
Early on, most U. S. States relied upon foreclosure by public sale, an innovation from the English law that remains the predominant method of foreclosure in the United States. In those states where redemption is practiced, the redemption period is usually, but not always, terminated by sale of the land. ${ }^{4}$

Since 1820 , many states have at one time or another experimented with statutorily-imposed redemption laws that extend the mortgagor's right of redemption beyond foreclosure. (In some cases, the mortgagor is allowed to remain in possession of the property during this period.) Changes in redemption laws have moved in accordance with broad trends. Table 1, constructed from information in Jones $(1882,1904,1928)$, Skilton (1943), and Mortgage Bankers Association (1997), contains historical and current information on state redemption laws where available. ${ }^{5}$

Historically, redemption laws have almost always been about protecting farmers from economic downturns that placed them under considerable economic duress. For example, Skilton (1943, p. 326) detects a small bulge in redemption legislation in the 1820 's due to the economic depression following the cessation of the Napoleonic wars. As Table 1 shows, in the early 1820's New York (in 1820), Tennessee (in 1821), Illinois (in 1825), Maine (in 1821), and Missouri (in 1821) all enacted legislation allowing a redemption period. A similar clustering of changes occurred in the 1890's, another period of economic difficulty, when Calfornia (in 1897), Idaho (in 1895), and Oregon (in 1895) all extended their statutes.

\footnotetext{
${ }^{4}$ Skilton (1943, page 319) writes that "Strict foreclosure has survived today as the usual remedy in only two states: Connecticut and Vermont, where English traditions are especially strong." His source for this observation is Hanna (1932). Mortgage Bankers Association (1997) verifies that this remains true today. ${ }^{5}$ See also Prather (1957) and Bridewell (1938), who provide some additional detail, but which essentially contain information similar to Skilton (1943).
} 
The trend over the past sixty years or so, however, has been for states to shorten their redemption periods or to eliminate them entirely. ${ }^{6}$ In 1938 , at the height of the Depression, 28 of 48 states in the sample had redemption laws (Bridewell, 1938), but by 1992 only 17 had redemption laws (Mortgage Bankers Assoc., 1997). Further, of those 17 states retaining their redemption laws, 14 had shortened the redemption period. ${ }^{7}$ This broad trend is not surprising, given the conjectured link between redemption and agriculture, coupled with the rather dramatic decrease in the importance of agriculture in the national economy over this time. However, it is interesting to note that the South, historically a heavily agricultural region, did not generally employ redemption statutes. As our empirical analysis will suggest, this may have been because agriculture in the South was not as heavily dependent on investment in improvements as in other parts of the country.

In spite of the time trend and the fluctuations in the nature of redemption laws over time, they have in fact remained remarkably stable over time. Comparison of the survey of redemption laws in various editions of Jones $(1882,1904,1928)$ with Skilton (1943) reveals that there was almost no change in mortgage redemption laws across states over the period $1882-1943 .^{8}$

\footnotetext{
${ }^{6}$ Of course, this does not preclude future passage of foreclosure moratoria, which temporarily suspend foreclosure in times of hardship (Skilton, 1943).

${ }^{7}$ Though he does not offer evidence to support his claim, Bauer (1985) reports that redemption laws were in general use from 1820 to 1920 , at which point they began to disappear, in part due to the efforts of legal scholars.

${ }^{8}$ This is even more interesting considering the findings of Alston (1984) on the response of state legislatures to the economic distress of farmers during the great depression through the passage of mortgage moratorium legislation. On the other hand, the national economy remained heavily agricultural over this entire time period; in 1880, for example, the percentage of people working in the agricultural sector was 30\%, and it remained around this level in 1930. (Kuznets and Thomas, 1957).
} 


\section{The Model}

Previous economic analyses of mortgage redemption laws have not provided a firm theoretical basis for there pervasiveness. Most authors have seen them as a product of the political interplay between creditors and debtors. ${ }^{9}$ While not denying the importance of these public choice factors, in this section we develop a theory that justifies redemption laws based on broader economic concerns.

Consider an individual (the mortgagor) who, at some point in the past, took out a mortgage to finance the purchase of a piece of property. Suppose that a balance of $B$ dollars (principal plus interest) is due at time $t=0$, the date of maturity. There is, however, some risk that the mortgagor will default due to random factors that affect his liquidity. We assume, however, that he can increase his chances of paying off the loan on time by investing in effort, $e$ (measured in dollars), prior to the due date. Let $p(e)$ be the probability that he will not default, where $p>0$ and $p^{\prime \prime}<0$.

Suppose that the value of the property to the mortgagor consists of two components: a market value $v$ and an owner-specific value $s$. In the case of commercial property (including farms), $v$ represents the present value of expected cash flows from the property, while $s$ represents the return from non-transferable investments, goodwill, plus any utility benefits of ownership (Aghion and Bolton, 1992; Hart, 1995: Chapter 5). For residential property, $v$ is the maximum offer that could be obtained on the market while $s$ is the mortgagor's "subjective value," reflecting, for example, his or her attachment to the land (Miceli and Sirmans, 1995).

\footnotetext{
${ }^{9}$ This view is not new, and strong arguments against redemption laws on the grounds that they are purely redistributive have been put forth by Prather (1957) and Bridewell (1938).
} 
In the event that the mortgagor has insufficient liquidity to pay off the mortgage on time (which occurs with probability $1-p(e)$ ), he could avoid default by selling the property if $v \geq B$. We assume he would always do so, either voluntarily or by foreclosure, and therefore we consider only properties for which $v<B$. We further assume, however, that $v+s>B$, for otherwise, the mortgagor would have no incentive to avoid default and would likely abandon the property.

The redemption period, if one exists, represents the period of time following default during which the mortgagor can reclaim the property. As noted above, equitable redemption allows the mortgagor to reclaim the property prior to the foreclosure sale by paying off the loan balance, whereas statutory redemption extends the grace period beyond the foreclosure sale for a set period of time. For purposes of the model, we do not formally distinguish between these cases. Instead, we simply suppose that there is a period of length $T \geq 0$, following default, during which the mortgagor can re-acquire the property by paying off $B$. In effect, $T$ is an extension of the maturity date for the mortgage. Let $q(T)$ be the probability that he does in fact redeem the property during this period, ${ }^{10}$ where

$$
q>0, \quad q(0)=0, \text { and } \quad q(\infty)=1
$$

The mortgagor takes the length of the redemption period as given and chooses effort, $e$, to maximize his private expected value of the property, given by

$$
V_{M}(e ; T)=[p(e)+(1-p(e)) q(T)](v+s-B)-e .
$$

The optimal effort level, $e_{M}(T)$, solves the first-order condition ${ }^{11}$

\footnotetext{
${ }^{10}$ Unlike $p$, we treat $q$ as depending only on time, though it would be straightforward to view it as a function of mortgagor effort as well.

${ }^{11} e_{M}(T)>0$ given $v+s>B$, and the second order condition holds given $p "<0$.
} 


$$
p^{\prime}(1-q(T))(v+s-B)=1
$$

Totally differentiating this equation yields

$$
\frac{\partial e_{M}}{\partial T}=\frac{p^{\prime} q^{\prime}}{p^{\prime \prime}(1-q)}<0 \text {. }
$$

The mortgagor's effort is therefore decreasing in the length of the redemption period. This reflects a potential moral hazard problem associated with lengthening of the redemption period and therefore provides the basis for limiting $T$ to a finite length (possibly zero).

To determine the optimal value of $T$, we write the expected social value of the property as

$$
V(T)=v+\left[p\left(e_{M}(T)\right)+\left(1-p\left(e_{M}(T)\right)\right) q(T)\right] s-e_{M}(T) .
$$

The derivative of (5) with respect to $T$ is given by

$$
\frac{\partial V}{\partial T}=(1-p) q^{\prime} s+\left[p^{\prime}(1-q) s-1\right]\left(\frac{\partial e_{M}}{\partial T}\right) .
$$

Using (3), we can rewrite this expression as

$$
\frac{\partial V}{\partial T}=(1-p) q^{\prime} s+p^{\prime}(1-q)(B-v)\left(\frac{\partial e_{M}}{\partial T}\right),
$$

which is ambiguous in sign. The first term, which is positive, represents the marginal benefit of lengthening $T$. It reflects the fact that a longer redemption period increases the chance that the mortgagor will retain the non-transferable value of the property, $s$. Offsetting this is the second term, which is the marginal cost of a longer redemption period. It captures the moral hazard effect noted above - namely, that as $T$ is lengthened, the mortgagor has less incentive to avoid default, which imposes a cost of $B-v$ on the mortgagee. The optimal redemption period, $T^{*}$, balances these two effects at the margin. 
It is clear from (7) that $s>0$ is necessary for a positive redemption period to be optimal, for otherwise, there would be no social benefit of extending the maturity date. It follows that redemption statutes (i.e., $T^{*}>0$ ) should be more prevalent in regions where landowners have invested more heavily in non-transferable capital, or where there is high subjective value associated with land ownership. This prediction, along with the public choice factors to be discussed below, forms the basis for the empirical analysis in the next section.

\section{Empirical Analysis}

The model described the fundamental tradeoff underlying redemption laws as being between the negative impact on incentives to prevent default on one hand and protection of owner-specific (non-marketable) land values on the other. In addition, it is undeniable that mortgage redemption laws have historically been driven by the longstanding public commitment to protect family farms against fluctuations in the value of agricultural land. For example, Skilton (1943, p. 329) cites the 1895 decision of the Kansas Supreme Court in Beverly v. Barnitz: ${ }^{12}$ “...Farms valued five years ago by both borrower and lender at $\$ 3000$ or $\$ 4000$, and mortgaged for $\$ 1000$, are now knocked down under the sheriff's hammer for less than the mortgage debt, the accumulations of a lifetime being often swept away by the shrinkage..." Further, Friedman (1985: 246) notes that in the nineteenth century, "[1]egislatures particularly in the West, found debtor relief politically irresistable." Prior research in related areas has also pointed to the possible

\footnotetext{
${ }^{12}$ Beverly v. Barnitz, 55 Kan. 466, 484 (1895).
} 
role of the agricultural sector in influencing the nature of lending policies across states. ${ }^{13}$ Such considerations emphasize the importance of political considerations.

In addition to economic and political factors, empirical work on the origins of laws must take account of the force of history. It is therefore important to choose a time period for analysis over which the issue at hand was relatively important, and for which sufficient data are available. For this reason, we selected independent variables from 1920, and chose as our dependent variable the state of redemption laws circa 1937 as reported in Bridewell (1938). Since there was little change in redemption laws over the period between 1900 and 1943, this configuration of the data positions us as close as possible to the origins of redemption laws while remaining a recent enough time period to admit useable data. In particular, it allows us to employ data similar to that employed by Alston (1984). In addition, this time period likely avoids most of the upheaval of the great depression, and therefore more accurately represents the everyday state of affairs in a given state's economy.

As a building block for our model, we initially consider a close relative of the specification that Alston employed to explain variations in states' decisions to adopt mortgage moratoria during the Great Depression. ${ }^{14}$ His model included two variables to capture the importance of the farm and the mortgage in a state's economy: the percentage of farm income in a state's GDP, and the percentage of farms that were mortgaged. Following Alston's work, we include data on (1) the percentage of mortgaged farms in 1920 (taken from the 1928 Statistical Abstract of the U. S.); and (2) the percentage of labor force employed in the agricultural sector in 1920 (taken from Kuznets and Thomas,

\footnotetext{
${ }^{13}$ See, for example, Alston (1984), who finds evidence for the impact of farm interests, and Hynes, Malani, and Posner (2003), who do not.
} 
1957). These variables capture the public choice forces that undoubtedly influenced the adoption of redemption laws.

We also include two additional variables to capture the importance of specific (non-transferable) investments suggested by the theory. First, we include the percentage of farm acres that were improved, taken from the 1928 Statistical Abstract of the U. S. This reflects the degree to which land improvement was important in the state's agricultural sector. Additionally, we include the ratio of the value of implements and machinery to the value of farm land and buildings. This is a further measure of how important non-land inputs were in determining the overall value of the land. Together, these variables serve as proxies for the non-transferable component of land value.

Table 2 presents the means of the dependent variable $(=1$ if a state had a redemption period c. $1937,=0$ if not) and the above explanatory variables for the sample as a whole and also for sub-samples grouped by region. ${ }^{15}$ Regional differences immediately suggest some broad trends. For example, of the three regions where agriculture was relatively important based on the percentage of labor employed on farms (the South, North Central, and West), the South stands out as having had the smallest percentage of states with redemption statutes (.31 compared to .92 in the North Central and .91 in the West). This may be explained by the confluence of public choice and investment concerns. The percentage of mortgaged farms in the South was much smaller than in the other two regions (.26 compared to .49 and .44$)$. In addition, farmers in the

\footnotetext{
${ }^{14}$ One possible interpretation of our model is as a long run specification of Alston's.

${ }^{15}$ States in the New England Mid Atlantic Region: Maine, Vermont, New Hampshire, Connecticut, Rhode Island, Massachusetts, New York, New Jersey, and Pennsylvania. States in the South: Maryland, Delaware, Virginia, North Carolina, South Carolina, Georgia, Florida, Kentucky, Tennessee, Alabama, Mississippi, Louisiana, Texas, Arkansas, and Oklahoma. States in the North Central: Indiana, Ohio, Illinois, Michigan, Wisconsin, Minnesota, Iowa, Nebraska, Kansas, North Dakota, and South Dakota. States in the West:
} 
North Central had a higher rate of improved land compared to the South (.70 versus .53), while farmers in the West had a higher ratio of added investments compared to the South (.30 versus .20). In the industrial northeast, farming was not an important activity during the sample period, which accounts for the low incidence of redemption laws there.

Table 3 presents the results of fitting some econometric models to this data. Models I and II are logistic models, where the dependent variable equals one if a redemption law was present in the state in 1937, and zero otherwise. By comparing models I and II, one gets the impression that the public choice variables, the percentage of farm labor in the state and the percentage of farms mortgaged, explain the bulk of the variation regarding the presence or absence of redemption laws. (This corresponds to Alston's (1984) findings.) However, the investment to value ratio is also statistically significant and of the correct sign, while the percentage of improved land in farms has the correct sign but is insignificant.

Model III applies a higher tech approach to the data by making use of variations in the statute length. In particular, it fits a Heckman selection model to the data by jointly estimating the probability that a state has a redemption law, and, given that a state has a redemption law, the impact of each of the independent variables on the length of the statutory period. This model was estimated using the logarithms of all variables while allowing for non-independence in the dependent variable across the four regions described in Table 2. ${ }^{16}$ The Chi-square test statistic for independence of the selection and

Montana, Idaho, Washington, Oregon, California, Colorado, Wyoming, Utah, Nevada, Arizona, and New Mexico.

${ }^{16}$ See Baker et al. (2002) for a similar approach to estimating and studying variation in state laws. It is interesting to note that many of the conceptual issues behind selection models were developed in the context of law and economics, and in particular in the study of state variation in anti-discrimination legislation. See Maddala (1982). 
statute length equation is 31.62 , which indicates that selection and length cannot be modeled independently.

Model III reveals some interesting features of the data. Note first that, while the public choice variables are significant in both the selection and statute length equations, the investment variables are only significant in the latter equation. Thus, it appears that the public choice variables play the primary role in explaining the presence of a statute in a particular state, whereas the investment variables only affect the determination of statute length. Specifically, those states with a larger percentage of improved land and a higher investment to value ratio adopt longer redemption periods, all else equal. Interestingly, the percentage of mortgaged farms appears with a positive sign in the selection equation, but with a negative sign in the statutory length equation. One interpretation of this result is that those states with a high percentage of mortgaged farms desired to extend some protection to borrowers by enacting a statute, but when determining the statute length, they took account of the possibly adverse impact of a longer redemption period on the overall mortgage market, and hence limited the length of the statutory period.

\section{Conclusion}

This paper has developed an economic analysis of mortgage redemption laws in the United States. The history of these laws displays both regional variation and sensitivity to economic cycles, reflecting their role in protecting farmers from loss of their land during periods of economic downturn. The importance of farming interests in a 
given state has therefore been a significant factor in bringing about the passage of these laws, as previous scholars have noted.

While not denying political considerations, we proposed a novel theoretical justification for redemption laws based on the hypothesized existence of non-transferable value associated with certain land uses that would be lost in the event of foreclosure. According to this theory, the optimal redemption period balances the benefit of protecting this value (i.e., lowering the probability that it will be lost) against the reduced incentive of the mortgagor to avoid default. The empirical analysis, which used cross-state data from the early twentieth century, verified the importance of both political and economic factors in explaining the presence and length of redemption statutes. 


\section{References}

Aghion, Philippe and Patrick Bolton. 1992. "An Incomplete Contracts Approach to Financial Contracting," 59 Review of Economic Studies 473-94.

Alston, Lee J. 1984. "Farm Foreclosure Moratorium Legislation: A Lesson from the Past," 74 American Economic Review 445-457.

Baker, Matthew, and Thomas J. Miceli. 2000. "Statutes of Limitations for Accident Cases: Theory and Evidence," 19 Research in Law and Economics 47-67.

Baker, Matthew, Thomas J. Miceli, C.F. Sirmans, and Geoffrey Turnbull. 2001. "Property Rights by Squatting: Land Ownership Risk and Adverse Possession," 77 Land Economics 360-370. . 2002. "Optimal Title Search,” 31 Journal of Legal Studies 139-158.

Bauer, Patrick B. 1985. Statutory Redemption Reconsidered: The Operation of Iowa's Redemption Statute in Two Counties Between 1881 and 1980, 71 Iowa Law Review 343-424.

Bridewell, David A. 1938. "The Effects of Defective Mortgage Laws on Home Financing," 5 Law and Contemporary Problems, 545-63.

Capone, Charles A. 1996. Providing Alternatives to Mortgage Foreclosure: A Report to Congress. Washington, D. C.: U. S. Department of Housing and Urban Development.

Friedman, Lawrence. 1985. A History of American Law. $2^{\text {nd }}$ Edition. New York: Touchstone Books.

Glaeser, Edward and Jose Scheinkman. 1998. "Neither a Borrower nor a Lender Be: An Economic Analysis of Interest Restrictions and Usury Laws," 41 Journal of Law and Economics 1-36.

Hanna, John. 1932. Cases and Materials on Security. Chicago: The Foundation Press.

Hart, Oliver. Firms, Contracts, and Financial Structure. Oxford: Oxford University Press, 1995.

Hynes, Richard M., Amp Malani, and Eric A. Posner. 2003. "The Political Economy of Property Exemption Laws," Working Paper.

Jaffe, Austin J., and Jeffery M. Sharp. 1996. Contract Theory and Mortgage Foreclosure Moratoria," 12 Journal of Real Estate Finance and Economics 77-96. 
Jones, Leonard A. 1882. Jones on Mortgages, $3^{\text {rd }}$ ed. Cambridge: Riverside Press. 1904. A Treatise on the Law of Mortgages of Real Property, $6^{\text {th }}$ ed. Indianapolis, The Bobbs-Merrill Company. 1928. A Treatise on the Law of Mortgages of Real Property, $8^{\text {th }}$ ed. Indianapolis, The Bobbs-Merrill Company.

Kuznets, Simon and Dorothy S. Thomas, eds. 1957. Population Redistribution and Economic Growth: United States, 1870-1950. Philadelphia: American Philosophical Society.

Maddala, G. S. 1983. Limited Dependent and Qualitative Variables in Econometrics. Cambridge: Cambridge University Press.

Mortgage Bankers Association. 1997. State Legislative and Regulatory Compilations: Selected Summaries of Real Estate Finance Laws. Washington, D. C.: Mortgage Bankers Association of America.

Miceli, Thomas J., and C.F. Sirmans. 1995. "The Economics of Land Transfer and Title Insurance," 10 Journal of Real Estate Finance and Economics 81-88.

Prather, William C. 1957. "Foreclosure of the Security Interest," 1957 University of Illinois Law Review 421-461.

Skilton, Robert H. 1943. "Developments in Mortgage Law and Practice," 17 Temple University Law Quarterly 315-384. 
Table 1: State Redemption Laws in Historical Perspective

\begin{tabular}{|c|c|c|c|}
\hline State & $\begin{array}{l}\text { Redemption } \\
\text { period } 1992\end{array}$ & $\begin{array}{l}\text { Redemption } \\
\text { period } 1937\end{array}$ & $\begin{array}{c}\text { Year of Statutory Origins, with Important } \\
\text { Modifications }\end{array}$ \\
\hline Alabama & 12 & 24 & $1842(24)$ \\
\hline Arizona & None & 6 & $1877(6)$ \\
\hline Arkansas & None & 12 & $1879(12)$ \\
\hline California & None & None & $1851(6), 1897(12)$ \\
\hline Colorado & 2.5 & 6 & $1861(6)$ \\
\hline Connecticut & None & None & \\
\hline Delaware & None & None & \\
\hline Florida & None & None & \\
\hline Georgia & None & None & \\
\hline Idaho & 6 & 12 & $1864(6), 1895(12)$ \\
\hline Illinois & 7 & 12 & $1825(12)$ \\
\hline Indiana & 3 & 12 & \\
\hline Iowa & 6 & 12 & \\
\hline Kansas & 12 & 18 & \\
\hline Kentucky & None & 12 & $1851(12)$ \\
\hline Louisiana & None & None & \\
\hline Maine & 12 & 12 & $1821(36), 1876^{*}$ \\
\hline Maryland & None & None & \\
\hline Massachusetts & None & None & \\
\hline Michigan & 6 & 12 & $1827(24), 1838(12), 1839$ (25) 1840 (12), 1846* \\
\hline Minnesota & 6 & 12 & \\
\hline Mississippi & None & None & \\
\hline Missouri & None & 12 & $1821(30), 1824(0) 1877(12)$ \\
\hline Montana & None & 12 & $1867(6)$ \\
\hline Nebraska & None & 9 & $1859(12), 1875(9)$ \\
\hline Nevada & None & 12 & $1861(6), 1933(12)$ \\
\hline New Hampshire & None & None & \\
\hline New Jersey & None & None & \\
\hline New Mexico & 1 & 9 & $1889(12)$ \\
\hline New York & None & None & $1820(12), 1837^{*}, 1839^{*}$ \\
\hline North Carolina & None & None & \\
\hline North Dakota & 6 & 12 & $1877(12)$ \\
\hline Ohio & None & None & \\
\hline Oklahoma & None & 6 & \\
\hline Oregon & None & 12 & $1885(4), 1895(12)$ \\
\hline Pennsylvania & None & None & \\
\hline Rhode Island & None & None & \\
\hline South Carolina & None & None & \\
\hline South Dakota & 6 & 12 & $1893(12)$ \\
\hline Tennessee & None & 24 & $1820(24), 1823 *, 1832^{*}$ \\
\hline Texas & None & None & \\
\hline Utah & 3 & 6 & $1870(6)$ \\
\hline Vermont & 6 & 12 & $1827(12.25)$ \\
\hline Virginia & None & None & \\
\hline Washington & None & 12 & $1869(6), 1886(12)$ \\
\hline West Virginia & None & None & \\
\hline Wisconsin & 6 & 12 & $1849(24), 1889(12)$ \\
\hline Wyoming & 3 & 6 & $1869(6)$ \\
\hline
\end{tabular}


Table 2: Means and means by region (Standard Deviations in Parantheses):

\begin{tabular}{|c|c|c|c|c|c|}
\hline Variable & $\begin{array}{l}\text { All States } \\
(\mathrm{N}=48)\end{array}$ & $\begin{array}{c}\text { New } \\
\text { England/Mid } \\
\text { Atlantic } \\
(\mathrm{N}=9)\end{array}$ & $\begin{array}{l}\text { North Central } \\
\qquad(\mathrm{N}=12)\end{array}$ & $\begin{array}{l}\text { South } \\
(\mathrm{N}=16)\end{array}$ & $\begin{array}{l}\text { West } \\
(\mathrm{N}=11)\end{array}$ \\
\hline $\begin{array}{l}\text { Redemption law } \\
\text { present in } 1938 ?\end{array}$ & $\begin{array}{c}0.58 \\
(0.50)\end{array}$ & $\begin{array}{c}0.22^{*} \\
(0.44)\end{array}$ & $\begin{array}{l}0.92^{*} \\
(0.28)\end{array}$ & $\begin{array}{l}0.31^{*} \\
(0.48)\end{array}$ & $\begin{array}{l}0.91^{*} \\
(0.30)\end{array}$ \\
\hline $\begin{array}{l}\text { Ratio of added } \\
\text { investments to } \\
\text { farm value (1920) }\end{array}$ & $\begin{array}{c}0.23 \\
(0.09)\end{array}$ & $\begin{array}{l}0.29^{*} \\
(0.07)\end{array}$ & $\begin{array}{l}0.16^{*} \\
(0.04)\end{array}$ & $\begin{array}{c}0.20 \\
(0.03)\end{array}$ & $\begin{array}{l}0.30^{*} \\
(0.13)\end{array}$ \\
\hline $\begin{array}{l}\text { Percentage } \\
\text { improved land in } \\
\text { farms (1920) }\end{array}$ & $\begin{array}{c}0.51 \\
(0.18)\end{array}$ & $\begin{array}{c}0.46 \\
(0.16)\end{array}$ & $\begin{array}{l}0.70^{*} \\
(0.11)\end{array}$ & $\begin{array}{c}0.53 \\
(0.10)\end{array}$ & $\begin{array}{l}0.31^{*} \\
(0.15)\end{array}$ \\
\hline $\begin{array}{l}\text { Percentage farm } \\
\text { labor (1920) }\end{array}$ & $\begin{array}{c}32.5 \\
(17.24)\end{array}$ & $\begin{array}{l}10.51^{*} \\
(9.16)\end{array}$ & $\begin{array}{c}33.84 \\
(13.76)\end{array}$ & $\begin{array}{l}43.91^{*} \\
(15.98)\end{array}$ & $\begin{array}{l}29.33 \\
(9.42)\end{array}$ \\
\hline $\begin{array}{l}\text { Percentage farms } \\
\text { mortgaged (1920) }\end{array}$ & $\begin{array}{c}0.38 \\
(0.13)\end{array}$ & $\begin{array}{c}0.38 \\
(0.08)\end{array}$ & $\begin{array}{l}0.49^{*} \\
(0.11)\end{array}$ & $\begin{array}{l}0.26^{*} \\
(0.09)\end{array}$ & $\begin{array}{l}0.44^{*} \\
(0.10)\end{array}$ \\
\hline
\end{tabular}

*Denotes significant from sample mean at $5 \%$ level or smaller. 
Table 3: Fitted Models.

\begin{tabular}{|c|c|c|c|c|}
\hline \multirow{2}{*}{$\begin{array}{l}\text { Independent } \\
\text { Variable }\end{array}$} & \multirow[t]{2}{*}{ I } & \multirow[t]{2}{*}{ II } & \multicolumn{2}{|c|}{ III } \\
\hline & & & $\begin{array}{l}\text { Selection } \\
\text { equation }\end{array}$ & $\begin{array}{l}\text { Statutory } \\
\text { Length } \\
\text { equation }\end{array}$ \\
\hline Constant & $\begin{array}{l}-14.20^{* * *} \\
(3.25)\end{array}$ & $\begin{array}{l}-7.07^{* *} \\
(1.97)\end{array}$ & $\begin{array}{c}0.89 \\
(1.08)\end{array}$ & $\begin{array}{l}2.27^{* *} \\
(0.36)\end{array}$ \\
\hline $\begin{array}{l}\text { Percent farms } \\
\text { mortgaged, } 1920\end{array}$ & $\begin{array}{l}17.61^{* *} \\
(5.56)\end{array}$ & $\begin{array}{l}14.49^{* *} \\
(4.45)\end{array}$ & $\begin{array}{l}3.76^{* *} \\
(0.62)\end{array}$ & $\begin{array}{l}-0.30^{* *} \\
(0.07)\end{array}$ \\
\hline $\begin{array}{l}\text { Percentage labor } \\
\text { force in } \\
\text { agriculture, } 1920\end{array}$ & $\begin{array}{l}0.09^{* *} \\
(.032)\end{array}$ & $\begin{array}{l}0.07^{* *} \\
(0.03)\end{array}$ & $\begin{array}{l}1.64^{* *} \\
(0.43)\end{array}$ & $\begin{array}{l}0.20^{* *} \\
(0.06)\end{array}$ \\
\hline $\begin{array}{l}\text { Percentage of } \\
\text { farm land } \\
\text { improved, } 1920\end{array}$ & $\begin{array}{l}3.25 \\
(2.75)\end{array}$ & - & $\begin{array}{c}0.29 \\
(0.17)\end{array}$ & $\begin{array}{l}0.51^{* *} \\
(0.07)\end{array}$ \\
\hline $\begin{array}{l}\text { Ratio of } \\
\text { investments to } \\
\text { farm value, } 1920\end{array}$ & $\begin{array}{l}12.76^{*} \\
(6.20)\end{array}$ & - & $\begin{array}{l}1.09 \\
(0.81)\end{array}$ & $\begin{array}{l}0.32^{* *} \\
(0.10)\end{array}$ \\
\hline Pseudo $\mathrm{R}^{2}$ & .42 & .34 & $\begin{array}{l}\text { Wald Chi square, } \\
\text { ind. Eqns. }\end{array}$ & 31.72 \\
\hline
\end{tabular}

Notes:

1) Standard errors in parenthesis below coefficients.

2) $* *$ denotes significance at $99 \%$ level, $*$ denotes significance at $95 \%$.

3) Model III was estimated using by maximum likelihood using the logarithms of all variables, and allowing for possible interdependence across the four regions described on table 2. 